Global Conferences Series:

Social Sciences, Education and Humanities (GCSSSEH), Volume 6, 2020

International Conference Fakultas Tarbiyah dan Keguruan Universitas Islam Negeri Imam Bonjol Padang (ICFTKUINIBP) 2020

DOI: https://doi.org/10.32698/icftk420

\title{
Cultivate Literacy in Learning to realize Independent Learning for Elementary School Children
}

\section{Membudayakan Literasi Dalam Pembelajaran Untuk Mewujudkan Merdeka Belajar Bagi Anak Sekolah Dasar}

\author{
Nurjani \\ Institut Agama Islam Negeri Takengon, Aceh, Indonesia \\ E-mail: nurjanijani83@gmail.com
}

\begin{abstract}
Freedom of learning is a new policy launched by the Indonesian Minister of Education and Culture, which is expected from this policy to make Indonesian education more advanced. The problem here is how do we as practitioners face the free learning policy that is likely to be implemented. This article offers practitioners or education in Indonesia to re-cultivate literacy in learning, in which literacy and the policy of independent learning, both have the same goal of creating meaningful learning for students, which prioritizes character building rather than ranking systems. Therefore, the purpose of this paper is to describe the importance of cultivating literacy in learning, so that there will be independent learning activities that are conducive, especially for elementary school students.
\end{abstract}

Keywords: Freedom to learn, literacy, integrated literacy and freedom of learning

\section{PENDAHULUAN}

Merdeka belajar merupakan 2 kosa kata yang tidak asing lagi didengar, apalagi bagi yang bergelut dibidang dunia pendidikan.Merdeka belajar adalah program kebijakan baru Kementerian Pendidikan dan Kebudayaan Republik Indonesia, yang dicanangkan oleh Menteri Pendidikan dan Kebudayaan RI Kabinet Indonesia Maju, Nadiem Anwar Makarim.

Merdeka belajar akan membuat nuansa belajar menjadi lebih nyaman, hal ini dikarenakan siswa dapat berdiskusi dengan guru, tidak hanya mendengarkan penjelasan guru, namun lebih mengutamakan pembentukan karakter siswa yang berani, mandiri, cerdik dalam bergaul, berkompetensi, memiliki adab dan sopan. Hal ini tidak mengutamakan sistem ranking, karena setiap anak memiliki bakat yang berbeda-beda.

Mustaghfiroh (2020) berpendapat bahwa merdeka belajar merupakan mengubah cara pandang dalam pendidikan, yang mana berasumsi bahwa siswa itu mempunyai kemampuan yang unik. Kemudian diharapkan memberikan asumsi untuk siswa menyelesaikan masalah mereka sendiri.Merdeka belajar juga tidak dianjurkan guru melakukan pelajaran secara otoriter.Pendidikan yang dilakukan secara otoriter dapat menjadi penghalang mencapai suatu tujuan yang baik.

Berdasarkan hal demikian, diharapkan kebijakan merdeka belajar yang dicanangkan oleh Mendikbud Nadiem Makarim, dapat memberikan kontribusi terhadap pendidikan Indonesia yang mempunyai arah dan tujuan yang jelas. Menjadi lebih maju, berkualitas dan sesuai dengan apa yang diharapkan serta searah dengan yang telah diamanatkan dengan UUD 1945.

Kebijakan merdeka belajar, mungkin adanya pro dan kontra dikalangan masyarakat. Sebenarnya tujuan merdeka belajar itu sederhana, yaitu agar siswa, guru maupun orang tua terlibat aktif dalam kegiatan belajar yang menyenangkan, yang mana menjadi dari proses pendidikan yang membahagiakan, serta dapat mengambil sebuah makna dalam melakukan suatu pendidikan kepada siswa dan akan bermuara kepada pembentukan karakter siswa yang kita harapkan. Berdasarkan hal demikian akan memberikan asumsi untuk siswa menyelesaikan masalah mereka sendiri. 
Agar terciptanya merdeka belajar yang kondusif, bisa kita membudayakan literasi dalam pembelajaran.Kebijakan merdeka belajar, sebagai momentum untuk mengembalikan literasi pendidikan, pendidikan yang memerdekakan.Pendidikan merupakan usaha yang dilakukan serta direncanakan untuk mewujudkan suasana belajar bagi siswa secara aktif dalam mengembangkan potensi yang mereka miliki.Agar literat dalam spiritual kegamaan, pengendalian diri, kepribadian, kecerdasan, akhlak mulia, serta keterampilan yang diperlukan.

Laksono (2018) berpendapat bahwa literasi tidak dapat dipisahkan dari dunia pendidikan.Literasi menjadi sebuah wadah untuk siswa mengenal, memahami, dan menerapkan ilmu yang didapat dibangku sekolah.Tanpa disadari literasi juga terkait dengan kehidupan siswa, baik di rumah maupun di lingkungan sekitarnya yang mana untuk menumbuhkan budi pekerti mulia.

Berdasarkan jabaran di atas, dapat disimpulkan bahwa merdeka belajar dapat dilakukan dengan kita kembali membudayakan literasi di dalam pembelajaran. Karena di dalam literasi terdapatnya tujuan yang diharapkan terhadap kebijakan merdeka belajar yang akan diberlakukan di dalam dunia pendidikan. Maka tujuan dari program ini adalah menumbuhkan budi pekerti siswa melalui kegiatan membaca dan menulis maupun kegiatan lainnya.Program ini dapat diberlakukan kepada siswa sejak dini, khususnya pada siswa yang masih duduk dibangku Sekolah Dasar (SD). Hal ini akan dapat tertanam di dalam diri mereka sejak dini, dan akan terbiasa sampai dijenjang pendidikan selanjutnya.

Tujuan pembahasan ini adalah mendeskripsikan pentingnya membudayakan literasi dalam pembelajaran, sehingga akan terwujudnya kegiatan merdeka belajar yang kondusif khususnya bagi siswa SD.

\section{METODE}

\section{Metode Penulisan}

Jenis penulisan tentang "Membudayakan Literasi dalam Pembelajaran untuk Mewujudkan Merdeka Belajar bagi Anak Sekolah Dasar”, penulis menggunakan studi literatur.Studi literatur ini berkenaan dengan metode pengumpulan data pustaka, yang mana membaca dan mencatat, serta mengolah materi penemuan.

Diperkuat oleh Sukardi (2010) yang mana penulisan ini pengumpulan datanya dilakukan dengan membaca literatur yang berkaitan dengan informasi serta relevansi terhadap topik yang dibahas.

Tujuan dari pembahasan ini adalah membudayakan literasi di dalam sebuah pembelajaran yang mana akan mewujudkan merdeka belajar yang kondusi khususnya bagi anak SD. Karena di dalam literasi terdapatnya tujuan dari merdeka belajar, yaitu dimana menumbuhkan budi pekerti siswa, sehingga bisa bermanfaat untuk diri mereka sendiri, bukan hanya pembelajaran mengutamakan sistem rangking.

\section{Teknik Pengumpulan Data}

Teknik pengumpulan data menggunakan studi pustaka, yaitu dilakukan dengan mengumpulkan datadata serta teori-teori yang berkaitan dengan membudayakan literasi di dalam sebuah pembelajaran yang mana akan mewujudkan merdeka belajar yang efektif khususnya bagi anak SD dari buku-buku maupun jurnaljurnal serta sumber-sumber yang relevan.

\section{Analisis Data}

Data yang diperoleh dari sumber-sumber yang ada, dianalisis secara kualitatif dengan metode berfikir deduktif normatif.

\section{HASIL DAN DISKUSI \\ Merdeka Belajar}

Akhir-akhir ini banyak kita dengar pembahasan tentang merdeka belajar.Gagasan tentang merdeka belajar dilontarkan oleh Mendikbud ketika memperingati hari guru tahun 2019.Secara sederhana merdeka belajar dapat dimaknai dengan memberikan kesempatan kepada siswa secara nyaman untuk belajar dengan keadaan tenang, santai, gembira dan tanpa stres dan tekanan. Namun juga memperhatikan bakat apa yang dimiliki oleh siswa, dari hal tersebut dapat membekali diri siswa menyelesaikan/ memecahkan masalah yang mereka hadapi dengan menanamkan nilai-nilai budi luhur di dalam diri mereka.

Pandangan Hamka tentang merdeka belajar (Setiawan:2016) menjelaskan bahwa, dalam proses pembelajaran harus dilakukan dengan membangun sebuah kemauan dan semangat, menciptakan suatu 
kebebasan dalam berpikir, dan juga terbebas dari segala ketakutan. Maka dari itu Ki Hajar Dewantara menggambarkan sekolah sebagai Taman Siswa, yaitu suatu tempat yang indah, menyenangkan, sehingga membuat siswa betah karena jauh dari ketakutan. Jika itu terjadi pembelajaran yang bermakna akan diperoleh oleh siswa.

Konsep merdeka belajar siswa diharapkan bersikap aktif dalam pembelajaran sehingga dapat menemukan cara belajar sesuai dengan apa yang dia inginkan. Guru di sini berfungsi sebagai fasilitator, mediator, dan sebagai teman sehingga membuat kondisi pembelajaran yang sedang berlangsung menjadi kondusif (Poedjiadi dalam Hamzah: 2008).

Herbert (2019) berpendapat bahwa merdeka belajar menggambarkan sebuah pembelajaran yang berkualitas, cepat, kritis, variatif, aplikatif, progresif, aktual dan faktual. Siswa belajar dengan mengutamakan kemerdekaan akan senantiasa bersemangat, optimis, kreatif dan selalu berani untuk mencoba suatu hal yang baru. Para siswa seperti ini biasanya menganggap ketika membaca buku yang bergizi tak kalah nikmatnya dengan menyantap sebuah makanan.

Konsep dari merdeka belajar merupakan sebuah tawaran dalam sistem pendidikan nasional, yang mana penataan ulang dalam menyongsong perubahan dan kemajuan bangsa. Hal ini dapat dilakukan dengan cara, mengembalikan hakikat pendidikan yang sebenarnya, yaitu sebuah pendidikan untuk memanusiakan manusia/ pendidikan yang membebaskan (Yamin \& Syahrir: 2020).

Berdasarkan jabaran di atas dapat disimpulkan bahwa adanya sebuah harapan ke depan dengan konsep merdeka belajar, yaitu agar murid merasa nyaman belajar serta berdiskusi dengan guru. Pembelajaran tidak harus dilakukan di dalam kelas, bisa juga dilakukan dengan auting class, dan tidak hanya mendengarkan penjelasan yang diberikan oleh guru akan tetapi lebih membenuk karakter siswa, yang berani, cerdik dalam bergaul, mandiri, beradap, sopan dan berkompetensi. Hal ini tidak saja mengandalkan sistem perangkingan.

Ada beberapa timbul pertanyaan, apa yang diharuskan praktisi dalam mencapai merdeka belajar yang kondusif? Hal ini bisa dilakukan dengan pendekatan personal, penggunaan metode, strategi, dll yang dapat mewujudkan kegiatan belajar yang menyenangkan dan terbebas dari perasaan tekanan. Sehingga tujuan merdeka belajar akan terwujud dengan baik.

\section{Literasi di dalam Pembelajaran}

Pembahasan sebelumnya telah disinggung tentang merdeka belajar, untuk selanjutnya akan dibahas tentang literasi di dalam pembelajaran. Literasi sebenarnya tidak dapat terpisahkan dari dunia pendidikan. Karena literasi menjadi sarana siswa untuk mengenal, memahami, serta menerapkan apa yang dia dapat di bangku sekolah. Literasi juga terkait dengan kehidupan siswa, baik di rumah maupun dilingkungan sekitar dimanapun mereka berada karena hal ini untuk menumbuhkan budi perkerti mulia di dalam diri mereka (Laksono, dkk: 2018).

Hastuti \& Lestari (2018) berpendapat bahwa literasi yang dilakukan oleh sekolah dalam pembelajaran guna menciptakan sebuah masyarakat yang literat, berarti masyarakat yang mempunyai skil untuk memahami dan mengaplikasikan apa yang dibaca lewat perilaku sehari-hari, masyarakat yang literat sangat diharapkan memiliki sebuah perilaku yang sesuai dengan apa yang dibaca dan dipahami. Pembiasaan hal positif yang diberikan kepada siswa di sekolah, perlu dibudayakan karena hal tersebut akan berdampak positif bagi kehidupan siswa.

Selain itu Cordon (dalam Ibadullah, dkk: 2017) menyatakan bahwa literasi adalah sebuah ilmu yang sangat menyenangkan, yang mana mampu membangun imajinasi siswa untuk menjelajah dunia dari ilmu pengetahuan yang mereka dapat. Kemudian nilai-nilai literasi akan tergambar ketika siswa berhasil menerapkan apa yang telah mereka pelajari di dalam kehidupan mereka.

Perlu sama kita ketahui bahwa literasi sebenarnya tidak selalu terkait dengan membaca dan menulis, namun semua komponen yang ada di dalam pendidikan bisa disajikan dengan pembelajaran literasi, misalnya baik lukisan, tarian, bacaan, hitungan, dll. Siswa dapat memaknai semua komponen tersebut, sehingga bisa bermanfaat untuk diri mereka sendiri.

Jadi membudayakan literasi di dalam sebuah pembelajaran itu sangat penting. Kenapa ini bisa disebut sangat penting, karena siswa harus bisa mengambil sebuah makna dari apa yang mereka pelajari. Siswa diharapkan tidak hanya sekedar membaca namun bisa mengambil apa maksud dari bacaan tersebut, nilai-nilai apa saja yang terkandung dalam bacaan tersebut. Karena kita tahu sesungguhnya apa yang dibaca oleh siswa atau apa yang dipelajari oleh siswa dapat membawa perubahan sepanjang hayat.

Dapat dikaitkan dengan ayat al-Qur'an dalam surat al-Isra' ayat 14 yang berbunyi:

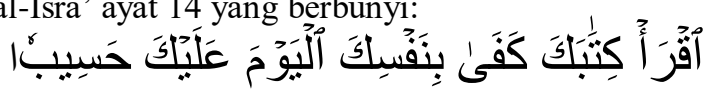


Artinya: "Bacalah kitabmu, cukuplah dirimu sendiri pada waktu ini sebagai penghisap terhadapmu"

Penjelasan ayat di atas, dimana saat umat manusia telah meninggal dunia, kemudian mereka dibangkitkan kembali dari alam kubur, maka di situlah setiap hamba akan mempertanggungjawabkan amal perbuatannya. Amalan dari manusia telah tercatat di dalam sebuah kitab. Mereka akan diminta untuk membacanya dan mempertanggungjawabkan apa yang telah mereka lakukan.

Maka dari itu kita sebagai praktisi dalam mendidik siswa, jangan biarkan hanya memberikan ilmu yang lepas, kita hanya menuntut patokan terhadap nilai atau rangking saja. Namun ajari mereka sebuah makna dari ilmu yang mereka dapat, karena semua akan mereka pertanggungjawabkan, maka dari itu akan menciptakan budi pekerti mulia di dalam diri mereka untuk menjalani kehidupan. Berdasarkan demikian, jika hal tersebut dapat dilakukan, maka makna literasi sebenarnya telah dapat kita capai yaitu menumbuhkan budi perkerti mulia di dalam diri mereka.

\section{Keterpanduan Kegiatan Literasi dalam Pembelajaran dengan Kebijakan Merdeka Belajar Khususnya bagi Anak Sekolah Dasar}

Pejabaran di atas, perlu kita ketahui bahwa adanya sebuah keterpaduan antara kegiatan literasi dalam pembelajaran dengan kebijakan merdeka belajar, yang mana tujuannya memiliki kesamaan yaitu menciptakan sebuah pembelajaran yang bermakna bagi siswa yang lebih mengutamakan pembentukan karakter siswa dari pada sistem rangking.

Maka dari itu, jika kebijakan merdeka belajar ini akan diberlakukan, para praktisi mungkin tidak perlu binggung, karena sesungguhnya kita perlu membudayakan kembali literasi di dalam sebuah pembelajaran. Hal ini sangat membantu guru dan siswa dalam mencapai merdeka belajar yang kondusif, dan pastinya akan bermakna untuk siswa.

Dapat kita kutip pendapat Retnaningdyah (2018) bahwa pengembangan dan penguatan karakter serta kegiatan literasi menajadi unsur yang penting dalam kemajuan sebuah Negara dalam menjalani kehidupan di era globalisasi.Forum Ekonomi Dunia 2015 telah memberikan gambaran tentang keterampilan abad ke 21 yang sebaiknya dimiliki oleh seluruh bangsa di dunia.Keterampilan tersebut meliputi literasi dasar, kompetensi dan karakter.

Agar pendidikan lebih baik, kini saatnya masyarakat ikut mengawal penerapan kebijakan merdeka belajar berjalan optimal. Hal ini memang tidak mudah seperti membalikkan telapak tangan, tapi dengan niat dan usaha semua akan dapat dijalani dengan baik.

Maka merdeka belajar merupakan sebuah momentum untuk memperkuat literasi pendidikan di Indonesia.Sehingga dapat memperkuat kualitas pendidikan dan memperbaiki mutu pembelajaran yang ada. Menjadi lebih maju, berkualitas dan sesuai dengan apa yang diharapkan serta searah dengan yang telah diamanatkan di dalam UUD 1945.

Kemudian kenapa pembahasan ditulisan ini kita ambil objeknya siswa yang masih duduk dibangku SD. Karena sejak dini mereka perlu dibekali bagaimana membudayakan literasi di dalam sebuah pembelajaran, sehingga mereka juga akan tahu apa itu merdeka belajar sebenarnya. Jika ditanamkan sejak dini, itu akan menjadi bekal bagi mereka agar terbiasa untuk memahami sebuah pembelajaran bukan hanya dari kulitnya saja, tetapi mereka juga harus mengkaji sampai ke inti-intinya, maka dari itu mereka akan mendapatkan pembelajaran yang berharga.

\section{KESIMPULAN DAN REKOMENDASI Kesimpulan}

Pembahasan di atas, menggambarkan bahwa betapa pentingnya para praktisi pendidikan di Indonesia perlu membudayakan literasi di dalam sebuah pembelajaran. Karena apa, hal ini akan memudahkan para praktisi menerapkan kebijakan merdeka belajar yang mungkin akan diberlakukan untuk sistem pendidikan di Indonesia.

Alasan yang dapat penulis berikan, kenapa kebijakan merdeka belajar bagus untuk dilakukan, karena hal ini akan memberikan kontribusi untuk kemajuan pendidikan Indonesia ke depannya. Karena kita tahu perkembangan zaman makin hari lebih menuntut seseorang untuk lebih maju dalam berpikir dan bertindak, itulah tantangan bagi praktisi untuk membenah apa yang harus diberikan kepada siswa agar mampu menghadapi perkembangan zaman.

Merdeka belajar memiliki tujuan yang mana lebih mengutamakan pembentukan karakter siswa yang berani, mandiri, cerdik dalam bergaul, berkompetensi, memiliki adab dan sopan.Hal ini tidak mengutamakan 
sistem ranking, karena setiap anak memiliki bakat yang berbeda-beda.Jika ini dapat kita lakukan, maka kekhawatiran terhadap siswa dalam menghadapi perkembangan zaman tidak perlu kita ragukan lagi.

Kemudian, membudayakan literasi di dalam pembelajaran dapat memberikan kontribusi agar terwujudnya merdeka belajar yang kondusif. Karena dapat kita lihat literasi di dalam pembelajaran siswa bukan hanya memahami ilmu yang diberikan, tetapi siswa juga diminta dapat menanamkan di dalam kehidupan mereka, yang mana akan menjadi bekal bagi mereka untuk menjalani kehidupan. Hal ini dapat dilakukan sejak mereka dini, ketika mereka masih duduk dibangku SD sangat tepat melakukan kegiatan tersebut, sehingga akan terbiasa sampai mereka dewasa.

\section{Rekomendasi}

Apapun kebijakan yang nantinya akan diberlakukan kita sebagai praktisi harus siap dan harus mencari pendekatan sebaik mungkin, bagaimana cara menghadapi kebijakan yang akan diberlakukan nantinya, khususnya kebijakan merdeka belajar. Membudayakan literasi di dalam pembelajaran bagi praktisi sangat berguna untuk menghadapi kebijakan merdeka belajar ini.Sehingga pendidikan lebih mengutamakan pembentukan karakter siswa yang berani, mandiri, cerdik dalam bergaul, berkompetensi, memiliki adab dan sopan.

\section{REFERENSI}

Hamzah.(2008). Teori Belajar Konstriktivisme.Online. Tersedia https://akhmadsudrajat.wordpress.com/2008/08/20/teori-belajar-konstruktivisme/

Hastuti, S. Lestari, N.A. (2018). Gerakan Literasi Sekolah: Implementasi Tahap Pembiasaan dan Pengembangan Literasi di SD Sukorejo Kediri. BASA TAKA, 1(2), 29-34

Herbert, F. (2019).Merdeka Belajar. Online. Tersedia https://www.kompasiana.com/syekhmuhammad/5df20d25d541df6ca8471992/merdeka-belajar-atau-belajarmerdeka?page=all

Ibadullah, dkk.(2017) Pembelajaran Literasi Berbasis Sastra Lokal.Media Gravika: Jawa Timur

Laksono, K. (2018). Strategi Literasi dalam Pembelajaran di Sekolah Menengah Pertama.Jakarta: Satgas GLS Ditjen Dikdasmen Kementerian Pendidikan dan Kebudayaan

Mustaghfiroh, S. (2020).Konsep "Merdeka Belajar" Perspektif Aliran Progresivisme John Dewey.Jurnal Studi Guru dan Pembelajaran, 3(1), 141-147

Retnaningdyah, P. dkk.(2018). Panduan Literasi. Jakarta: Bumi Aksara

Setiawan, B.G. (2016). Kemerdekaan dalam Pandangan HAMKA.Jakarta: Bumi Aksara

Sukardi. (2010). Metodologi Penelitian Pendidikan: Komptensi dan Praktiknya. Jakarta: Bumi Aksara

Yamin, M. Syahrir. (2020). Pembangunan Pendidikan Merdeka Belajar (Telaah Metode Pembelajaran). Jurnal Ilmiah Mandala Education, 6(1), 126-136 